\title{
PENGARUH MINAT MEMBACA TERHADAP HASIL BELAJAR SEJARAH SISWA KELAS X SMA NEGERI 1 KOTO XI TARUSAN
}

\author{
Syahril, Wahyuli Lius Zain \\ Prodi Tadris IPS-Sejarah Fakultas Tarbiyah dan Keguruan UIN IB Padang
}

\begin{abstract}
Abstrak
Penelitian ini dilatarbelakangi oleh permasalahan yang tampak ketika melakukan observasi pada tanggal 25 Oktober 2016 di SMA Negeri 1 Koto XII Tarusan, yaitu siswa malas membaca materi sejarah, tidak mencatat materi yang disampaikan oleh guru, serta siswa jarang ke perpustakaan sekolah untuk membaca. Kondisi belajar siswa dan rendahnya hasil belajar pada mata pelajaran sejarah siswa kelas X SMA N 1 Koto XI Tarusan, tidak terlepas dari beberapa faktor yang mempengaruhinya. Minat membaca pada mata pelajaran sejarah tersebut adalah salah satu faktor internal yang dapat mempengaruhi hasil belajar sejarah siswa. Tujuan penelitian ini adalah untuk mengetahui pengaruh minat membaca terhadap hasil belajar sejarah sisw kelas X SMA N 1 Koto XI Tarusan. Penelitian ini adalah penelitian Ex post facto yang bertujuan untuk ada atau tidak hubungan antara dua variable. Populasi dalam penelitian ini adalah siswa kelas X.2, kelas X.4, dan X.6 SMA N 1Koto XI Tarusan yang berjumlah 109 orang. Sampel dalam penelitian ini adalah 37 orang yaitu 18 orang dari kelas X.2 dn 19 orang dari kelas X.4. sumber data dalam penelitian ini adalah siswa kelas X SMA N 1 Koto XI Tarusan. Metode pengumpulan data menggunakan angket dan studi dokumentasi sedang teknik pengolahan data dalam penelitian ini adalah menggunakan rumus korelasi Pearson Product Mment (PPM) dan untuk menguji keberartian koefisien korelasi r, diuji dengan menggunakan uji t. Tingkat persentase minat membaca dikategorikan rendah dan untuk penilaian hasil sejarah siswa dikategorikan rendah. Hubungan variable $\mathrm{X}$ dan $\mathrm{Y} \mathrm{r}_{\text {hitung }}>\mathrm{r}_{\text {tabel }}(0,901>0,325)$ dan untuk menghitung keberartian koefisien korelasi terhadap kedua variabel tersebut didapat $t_{\text {hitung }}>t_{\text {tabel }}(19,232>2,042)$ pada taraf signifikan 5\% dan untuk kontribusinya hbungan minat membaca dengan hasil belajar sejarah siswa sebesar $81 \%$. Jadi, hasil analisis data yang diperoleh, dapat diambil kesimpulan bahwa $\mathrm{H}_{\mathrm{i}}$ ditolak, dan $\mathrm{H}_{\mathrm{a}}$ diterima artinya terdapat pengaruh yang signifikan antara minat membaca terhadap hasil belajar sejarah siswa kelas X SMA Negeri 1 Koto XI Tarusan.
\end{abstract}

Kata Kunci : Pengaruh minat baca, hasil belajar, Siswa SMA Kelas X, Koto XI Tarusan

\section{Pendahuluan}

Minat adalah suatu rasa lebih suka dan rasa ketertarikan pada suatu hal atau aktivitas, tanpa ada yang menyuruh. Minat pada dasarnya adalah penerimaan akan suatu hubungan antara diri sendiri dengan sesuatu di luar diri. Semakin kuat atau dekat hubungan tersebut, semakin besar minat (Slameto, 2003: 180).

Sedangkan membaca merupakan aktivitas kompleks yang memerlukan sejumlah besar tindakan terpisah-pisah, mencakup penggunaan pengertian, khayalan, pengamatan, dan ingatan. 
Bond mengemukakan bahwa membaca merupakan pengenalan simbol-simbol bahasa tulis yang merupakan stimulus yang membantu proses mengingat tentang apa yang dibaca, untuk membangun suatu pengertian melalui pengalaman yang telah dimiliki (Mulyono Abdurrahman, 2003: 200)

\section{Faktor yang Mempengaruhi Minat Membaca}

Secara teoritis dan global, faktor-faktor yang mempengaruhi minat membaca adalah sebagai berikut:

\section{a. Faktor Internal}

Faktor internal adalah faktor yang berasal dari dalam diri anak itu sendiri, ini berarti bahwa setiap anak yang telah dilahirkan telah membawa potensi minat dari hereditasnya. Minat ini bentuknya masih sangat sederhana atau mengarah kepada pemenuhan yang sifatnya biologis (Lester D. Crow, 1982: 124)

b. Faktor Eksternal

Ada dua golongan besar yang termasuk faktor luar yang mempengaruhi manusia. Dua golongan itu ialah golongan organis, yaitu manusia, binatang dan tumbuh-tumbuhan dan golongan anorganis termasuk di dalamnya adalah keadaan alam dan benda-benda (Agus Suyanto, 2005: 177). Lingkungan keluarga sebagai lingkungan yang pertama dan utama dikenal anak, sangat berpengaruh terhadap anak. Berikut pernyataan Surachman sehubungan dengan pengaruh keluarga terhadap anak dalam interaksi sosial. Sedemikian pentingnya sehingga dapat dikatakan bahwa sifat interaksi sosial dalam keluarga banyak sekali menentukan arah dan sifat perhubungan adolesen yang baik maupun yang buruk (Surachman Winarno, 1980: 196).

\section{Hasil Belajar}

1. Belajar

Secara psikologis belajar merupakan suatu proses perubahan yaitu perubahan tingkah laku sebagai hasil dari interaksi dengan lingkunganya dalam memenuhi kebutuhan hidupnya. Perubahan-perubahan tersebut akan nyata dalam seluruh aspek tingkah laku (Slameto, 2003: 2).

Belajar adalah suatu proses, suatu kegiatan dan bukan suatu hasil atau tujuan. Belajar bukan hanya mengingat, akan tetapi lebih luas daripada itu, yakni mengalami. Hasil belajar 
bukan suatu penguasaan hasil latihan, melainkan perubahan kelakuan (Oemar Hamalik, 2011: 36).

Sedangkan tujuan belajar (Dalyono, 2012: 48) meliputi:

a. Mengadakan perubahan di dalam diri antara lain tingkah laku

b. Mengubah kebiasaan dari yang buruk menjadi baik

c. Mengubah sikap dari negatif menjadi positif

d. Menambah pengetahuan dalam berbagai bidang ilmu, misalnya tidak bisa membaca, menulis dan berhitung menjadi bisa semuanya.

Hamalik menyatakan bahwa tujuan belajar adalah sejumlah hasil belajar yang menunjukan bahwa siswa telah melakukan perbuatan belajar, yang umumnya meliputi pengetahuan, keterampilan dan sikap-sikap yang baru, yang diharapkan tercapai oleh siswa. Tujuan belajar adalah suatu deskripsi mengenai tingkah laku yang diharapkan tercapai oleh siswa setelah berlangsungnya proses belajar. Tujuan belajar merupakan cara yang akurat untuk menentukan hasil pembelajaran (Oemar Hamalik, 2011: 73).

\section{Pengertian Hasil Belajar}

Hasil belajar adalah perubahan tingkah laku yang timbul, misalnya dari yang tidak tahu menjadi tahu, timbulnya pertanyaan baru, perubahan dalam tahap kebiasaan, perkembangan sikap sosial dan emosional siswa (Oemar Hamalik, 2008: 2). Hasil belajar adalah kemampuan yang diperoleh anak setelah melalui kegiatan belajar. Belajar itu sendiri merupakan suatu proses dari seseorang yang berusaha untuk memperoleh suatu bentuk perubahan perilaku yang relatif menetap. Dalam kegiatan belajar yang terprogram dan terkontrol yang disebut kegiatan pembelajaran atau kegiatan instruksional (Mulyono Abdurrahman, 2003: 37).

Faktor-faktor yang menentukan pencapaian hasil belajar:

a. Faktor Internal (yang berasal dari dalam diri)

1) Kesehatan

2) Inteligensi dan Bakat

3) Minat dan Motivasi

4) Cara Belajar

b. Faktor Eksternal (yang berasal dari luar diri)

a) Keluarga

530 | Seminar Nasional Sejarah ke 4 Jurusan Pendidikan Sejarah Universitas Negeri Padang 
b) Sekolah

c) Masyarakat

d) Lingkungan Sekitar

\section{Pembelajaran Sejarah di Sekolah}

1. Pengertian Pembelajaran Sejarah

Geografi, sejarah, dan antropologi merupakan disiplin ilmu yang memiliki keterpaduan yang tinggi. Khususnya, Pembelajaran Sejarah memberikan wawasan berkenaan dengan peristiwa-peristiwa dari berbagai periode (Trianto, 2014: 171). Mata Pelajaran sejarah sering dianggap sebagai pelajaran hafalan dan membosankan. Pembelajaran ini dianggap tidak lebih dari rangkaian angka tahun dan urutan peristiwa yang harus diingat kemudian diungkap kembali saat menjawab soal-soal ujian. Pembelajaran sejarah yang selama ini terjadi di sekolah-sekolah dirasakan membosankan. Menurut cara pandang Pedagogy Kritis, pembelajaran sejarah seperti ini dianggap lebih banyak memenuhi hasrat dominant group seperti rezim yang berkuasa, kelompok elit, pengembang kurikulum dan lain-lain, sehingga mengabaikan peran peserta didik sebagai pelaku sejarah zamannya (Boyi Anggara, 2007: 100).

\section{Tujuan Pelajaran Sejarah di Sekolah}

Sejarah adalah mata pelajaran yang menanamkan pengetahuan dan nilai-nilai mengenai proses perubahan dan perkembangan masyarakat Indonesia dan dunia pada masa lampau hingga kini. Orientasi pembelajaran sejarah di tingkat SMA bertujuan agar siswa memperoleh pemahaman ilmu dan memupuk pemikiran historis dan pemahaman ilmu membawa pemerolehan fakta dan penguasaan ide-ide dan kaedah sejarah (Isjoni, 2007: 71).

\section{Metode Penelitian}

\section{A. Jenis Penelitian}

Jenis penelitian ini adalah penelitian ex post facto, karena penelitian ini tidak mencoba memanipulasi variabel penelitian. Penelitian ini dilakukan untuk meneliti peristiwa yang telah terjadi dan kemudian menelusurinya ke belakang melalui data untuk menentukan faktor-faktor yang mendahului atau yang menentukan sebab-sebab yang memungkinkan peristiwa itu terjadi. 
Karlinger menyatakan penelitian ex post facto adalah penyelidikan empiris yang sistematis dimana ilmuwan tidak mengendalikan variabel bebas secara langsung karena eksistensi dari variabel tersebut telah terjadi, atau karena variabel tersebut pada dasarnya tidak dapat dimanipulasi. Kesimpulan tentang adanya hubungan di antara variabel tersebut dibuat berdasarkan perbedaan yang mengiringi variabel bebas dan variabel terikat, tanpa intervensi langsung. Sementara itu menurut Gay penelitian ex post facto adalah penelitian dimana peneliti berusaha menentukan penyebab atau alasan, untuk keberadaan perbedaan dalam perilaku atau status dalam kelompok individu (Emzir. 2013: 119). Penelitian ex post facto yang peneliti lakukan adalah mengenai Pengaruh antara Minat Membaca terhadap Hasil Belajar Sejarah Siswa Kelas X SMA Negeri 1 Koto XI Tarusan.

\section{B. Populasi Dan Sampel}

\section{Populasi}

Dalam penelitian ini yang menjadi populasi adalah siswa yang hanya diajar oleh Ibuk Dra. Susi Rusfita saja yaitu kelas X.2, X.4 dan X.6 SMA Negeri 1 Koto XI Tarusan tahun ajaran 2016/2017, dengan jumlah siswa sebanyak 109 orang.

2. Sampel

Kelas yang dijadikan sampel dalam penelitian ini yaitu kelas X.2 dan X.4 yang mana dari kedua kelas tersebut di ambil sampel 18 orang dari kelas X.2 dan 19 orang dari kelas X.4

\section{Variabel dan Data Penelitian}

1. Variabel Penelitian

a. Variabel Bebas

Dalam penelitian ini yang menjadi variabel bebasnya adalah Minat Membaca (X).

b. Variabel Terikat

Dalam penelitian ini yang menjadi variabel terikat adalah Hasil Belajar Sejarah Siswa (Y).

2. Data Penelitian

a. Data Primer 
Data primer merupakan data yang didapat dari sumber pertama, dari penelitian ini data primernya didapat dari responden yang mengisi angket minat membaca yaitu siswa kelas X SMA Negeri 1 Koto XI Tarusan yang dijadikan sampel.

b. Data Sekunder

Data sekunder diperoleh dari data hasil belajar sejarah, yaitu nilai raport UTS (ujian tengah semester) di leger kepala sekolah dan wali kelas.

\section{Instrumen Penelitian dan Teknik Pengumpulan Data}

Jenis instrumen yang digunakan dalam penelitian ini adalah angket. Angket digunakan untuk mengetahui pengaruh minat membaca terhadap hasil belajar sejarah. Teknik pengumpulan data dalam angket yang dilakukan dengan cara memberi seperangkat pertanyaan atau pernyataan tertulis kepada responden untuk di jawabnya. Angket ini diberikan kepada siswa untuk memperoleh informasi mengenai minat membaca terhadap pelajaran sejarah. Angket disusun sendiri oleh peneliti dengan menggunakan langkah sebagai berikut:

1. Merumuskan Tujuan Penyusunan Angket

Angket yang disusun bertujuan untuk mengetahui minat membaca terhadap hasil belajar sejarah.

2. Memiliki Format Angket

Format yang digunakan dalam angket ini berupa pernyataan tertulis yang responden isi dengan memilih salah satu jawaban yang sesuai dengan keadaan yang sesungguhnya.

3. Memilih Model Jawaban

Model respon yang dipilih dan digunakan dalam angket ini adalah model skala likert, karena jenis data yang akan diperoleh di asumsikan sebagai data interval.

4. Merumuskan Indikator Pengembangan Instrumen

Untuk merumuskan indikator pengembangan instrumen dalam penelitian ini adalah dengan menetapkan indikator minat membaca sebagai acuan dalam menetapkan kisi-kisi yang akan diberikan kepada siswa.

5. Membuat Butir-Butir Angket

Butir angket dibuat berdasarkan indikator-indikator yang telah dirumuskan di atas, butir-butir dibuat dalam bentuk pernyataan yang menggambarkan minat membaca. Selanjutnya dibuat alternatif jawaban terhadap pernyataan tersebut untuk setiap butir dengan menggunakan model skala likert. 


\section{Uji Coba Instrumen}

Uji coba instrumen dilakukan pada siswa kelas X.6 SMA Negeri 1 Koto IX Tarusan yaitu terdiri dari 30 orang peserta didik.

\section{Teknik Analisis Data dan Uji Hipotesis}

1. Melakukan Skoring

2. Proses Tabulasi

3. Uji Hipotesis

$$
r_{x y}=\frac{N \cdot \Sigma x Y-\sum x \cdot \Sigma y}{\sqrt{\left(N \cdot \Sigma X^{2}-(\Sigma X)^{2}\right)\left[N \cdot \Sigma Y^{2}-(\Sigma Y)^{2}\right)}}
$$

Dimana :

$r_{x y} \quad=$ Koefisien korelasi masing-masing item

$\mathrm{N} \quad$ = jumlah sampel yang diteliti

$\mathrm{X}=$ minat membaca $($ variabel $\mathrm{x})$

$\mathrm{Y} \quad=$ hasil belajar (variabel $\mathrm{y})$

$\sum X \quad=$ Jumlah variabel $\mathrm{x}$

$\sum X^{2}=$ Jumlah kuadrat variabel $\mathrm{x}$

$\sum Y=$ Jumlah variabel $\mathrm{y}$

$\sum Y^{2}=$ Jumlah kuadrat variabel $\mathrm{y}$

$\sum X Y=$ Jumlah hasil kali antara variabel $\mathrm{X}$ dan $\mathrm{Y}$.

\section{Hasil Penelitian}

\section{A. Gambaran Umum SMA N I Koto XI Tarusan}

Pada tahun 1979 berdirilah SMAN Tarusan yang merupakan kelas jauh dari SMA Painan, yang pada waktu itu menumpang di lokasi SD Sawah Liat Tarusan. Berkat kerja keras para pendiri SMAN Tarusan, maka pada tahun 1980 didapatkanlah tanah wakaf dari bapak M.Dihir di desa Kapuh, Kec. Koto XI Tarusan, sebagaimana lokasi SMAN 1 Tarusan sekarang. Pada tahun 1980 itu siswa kelas jauh dari SMA Painan berjumlah 2 lokal, dan di kelola oleh Bapak Bustami sebagai ketua dan wakilnya Bapak Marlis, BA, sedangkan pengelola operasionalnya langsung dipercayakan kepada Bapak Syahrial R dan pegawai tata usaha yaitu Ibuk Erma Taher. Tahun 1981 setelah lolos akreditasi, maka nama SMAN Tarusan diubah menjadi SMAN 1 Tarusan. 
SMAN 1 Tarusan saat ini dipimpin oleh bapak Drs. Masdal Fitri, M.Si dibantu oleh empat orang wakil dan satu orang Kepala Tata Usaha. Jumlah tenaga pendidik di sekolah ini sebanyak 87 orang, dan karyawan sebanyak 17 orang. Jumlah siswa saat ini 1132 orang. Saat ini, akreditasi SMAN 1 Tarusan adalah "A". Di sekolah ini diterapkan Kurikulum Tingkat Satuan Pedidikan (KTSP) untuk seluruh kelas, X, XI dan XII.

\section{B. Deskripsi Data}

Dalam penelitian ini, ada dua variabel yang dikorelasikan yaitu variabel bebas dan variabel terikat. Variabel bebas yakni Minat Membaca Sejarah (X), dan variabel terikatnya yaitu Hasil Belajar Sejarah Siswa (Y). Berdasarkan penelitian maka diperoleh data mengenai minat membaca terhadap hasil belajar sejarah siswa SMA Negeri 1 Koto XI Tarusan melalui penyebaran angket dan pengambilan hasil ujian UTS (ujian tengah semester ganjil) pada tahun ajaran 2016-2017.

Berdasarkan pernyataan yang ada di dalam angket penelitian minat membaca terhadap mata pelajaran sejarah yang berjumlah 33 pernyataan. Kemudian, angket tersebut disebarkan kepada sampel yang sudah ditentukan peneliti yaitu sebanyak 37 orang siswa SMA Negeri 1 Koto XI Tarusan. Data yang terdapat pada angket tersebut digunakan untuk mengetahui seberapa besar minat membaca siswa dalam mempelajari mata pelajaran sejarah. Hasil belajar siswa didapat dengan pengolahan data melalui beberapa tahapan. Untuk lebih jelas mengenai deskripsi datanya akan dikaji pada masing-masing variabel.

Deskripsi data minat membaca dapat diketahui melalui perhitungan statistik sehingga terdapat hasil dari sebaran angket tersebut yang hasilnya mewakili siswa kelas X SMA Negeri 1 Koto XI Tarusan. Minat membaca dari pengolahan kategori terdapat hasilnya kategori Rendah tidak ada, kategori Cukup 3 Orang, kategori Tinggi 24 Orang dan kategori Tinggi Sekali 10 orang siswa. Dalam kata lain, bahwa minat membaca kelas X SMA Negeri 1 Koto XI Tarusan berdasarkan pengolahan data terdapat $34 \%$ siswa yang minat membacanya tinggi.

Deskripsi data hasil belajar akhir semester ganjil siswa pada mata pelajaran sejarah di kelas X SMA Negeri 1 Koto XI Tarusan terlihat dari pengolahannya bahwa kategori Sangat Tinggi tidak ada, kategori Tinggi 21 orang siswa, kategori Sedang sebanyak 14 orang siswa,

kategori Kurang 2 orang siswa dan kategori Sangat Kurang tidak ada. Jadi, hasil belajar siswa kelas X SMA Negeri 1 Koto XI Tarusan dalam keadaan tinggi sebanyak 28\% dan sisa lainya terdapat pada kategori lainnya. 


\section{Pengaruh Minat Membaca Terhadap Hasil Belajar Sejarah}

Hipotesis penelitian adalah terdapat pengaruh minat membaca terhadap hasil belajar pada mata pelajaran sejarah. Maka hipotesis statistik dalam penelitian ini adalah:

Hi : Jika $\mathrm{t}$ hitung $<\mathrm{t}$ tabel data ditolak berarti tidak ada pengaruh yang signifikan antara minat membaca terhadap hasil belajar sejarah siswa.

Ha: Jika t hitung > t tabel data diterima berarti ada pengaruh yang signifikan antara minat membaca terhadap hasil belajar sejarah siswa

Untuk menguji data antara skor angket minat membaca terhadap hasil belajar mata pelajaran sejarah di SMA Negeri 1 Koto XI Tarusan terlebih dahulu dikorelasikan kedua variabel tersebut

$$
\begin{aligned}
& r_{x y}=\frac{N \sum X Y-\left(\sum X\right)\left(\sum Y\right)}{\sqrt{\left[N\left(\Sigma X^{2}\right)-(\Sigma X)^{2}\right]\left[N\left(\Sigma Y^{2}\right)-(\Sigma Y)^{2}\right]}} \\
& \frac{(37)(264834)-(3408)(2872)}{\left.\sqrt{\{37 \times 321530}-(3408)^{2}\right\}\{37 \times 224380)-(2872)^{2}}
\end{aligned}
$$

$\frac{9798858-9787776}{\sqrt{(11896610}-11614464) \cdot(8302060-8248384)}$
$\frac{11082}{\sqrt{(282146)(53676)}}$
$\frac{11082}{\sqrt{15144468696}}$
$\frac{11082}{12306}=0,901$

Dari perhitungan koofisien korelasi diatas didapat $r_{\text {hitung }}=0,901>r_{\text {tabel }}=0,325$. Jadi, terdapat pengaruh minat membaca terhadap hasil belajar sejarah siswa SMA Negeri 1 Koto XI Tarusan dengan $r$ hitung $=0,901$ (tergolong sangat kuat).

\section{Uji Hipotesis}


Uji hipotesis dilakukan setelah didapatkan koefisien korelasi $(r)$ di atas maka pengujian hipotesis statistik dilanjutkan dengan uji keberartian korelasi dengan menggunakan rumus $t$ hitung sebagai berikut:

$$
\begin{aligned}
& t_{\text {hitung }}=\frac{r \sqrt{N-2}}{\sqrt{1-r^{2}}}=\frac{0,901 \sqrt{37-2}}{\sqrt{1-(0,901)^{2}}} \\
& t_{\text {hitung }}=\frac{0,901 \sqrt{35}}{\sqrt{1-0,811801}}=\frac{0,901.5,916}{0,277145} \\
& t_{\text {hitung }}=\frac{5,330316}{0,277145}=19,232
\end{aligned}
$$

Kaidah pengujian:

Jika t hitung $\geq$ dari $t$ tabel, maka signifikan.

Jika t hitung $\leq$ dari $t$ tabel, maka tidak signifikan.

Berdasarkan perhitungan di atas, dengan ketentuan tingkat kesalahan $\alpha=0,05 ; \mathrm{db}=\mathrm{N}-2$ $=37-2=35$ sehingga didapat $t_{\text {tabel }}=2,042$. Ternyata $t_{\text {hitung }} \geq$ dari $t_{\text {tabel }}$ atau 19,232 $>2,042$. Kesimpulan: variabel $(\mathrm{X})$ berpengaruh secara signifikan terhadap variabel $(\mathrm{Y})$.

Berdasarkan pengolahan data di atas dapat disimpulkan bahwa terdapat pengaruh yang signifikan antara hasil belajar sejarah siswa dengan minat membaca di SMA Negeri 1 Koto XI Tarusan, dibuktikan dengan pengolahan data bahwa $t_{\text {hitung }} \geq t_{\text {tabel }}$. Hal tersebut dapat terlihat bagaimana pengaruhnya $\mathrm{r}_{\text {hitung }}=0,901>\mathrm{r}_{\text {tabel }}=0,325$ sangat kuat untuk signifikannya $\mathrm{t}_{\text {hitung }}=$ $19,232>t_{\text {tabel }}=2,042$.

Untuk melihat besarnya kontribusi variabel $\mathrm{X}$ terhadap variabel $\mathrm{Y}$ dapat digunakan rumus sebagai berikut:

$$
\begin{aligned}
\mathrm{KD} & =\mathrm{r}^{2} \times 100 \% \\
\mathrm{KD} & =\text { Koefisien Determinasi } \\
\mathrm{r}^{2} & =(0,901) \\
\mathrm{KD} & =(0,901)^{2} \times 100 \%=(0,811) \times 100 \% \\
\mathrm{KD} & =81 \%
\end{aligned}
$$

Artinya: bahwa minat membaca memberikan kontribusi kepada hasil belajar sejarah siswa sebesar $81 \%$ dan sisanya ditentukan oleh variabel lain. Jadi, semakin tinggi minat membaca maka semakin besar hasil belajarnya. 


\section{Pembahasan}

Penelitian ini telah menemukan gambaran tentang pengaruh minat membaca $(\mathrm{X})$ terhadap hasil belajar (Y) siswa kelas X pada mata pelajaran Sejarah di SMA Negeri 1 Koto XI Tarusan. Sebagaimana yang telah dinyatakan dalam BAB II oleh Syah bahwa Minat (Interest) berarti kecenderungan dan kegairahan yang tinggi seseorang terhadap sesuatu. Minat dapat menghubungkan kualitas pencapaian hasil belajar siswa dalam bidang-bidang studi tertentu (Muhibbin Syah, 2007:136). Adanya minat terhadap objek yang dipelajari akan mendorong orang untuk mempelajari sesuatu dan mencapai hasil belajar yang maksimal. Karena minat merupakan komponen psikis yang berperan mendorong seseorang untuk meraih tujuan yang diinginkan, sehingga ia bersedia melakukan kegiatan berkisar objek yang diminati (Nyayu, Khodijah, 2014: 59).

Setelah melakukan uji coba pada kelas X.6 di SMA Negeri 1 Koto XI Tarusan yang diambil sebanyak 30 orang siswa, kemudian dilakukan analisis uji coba instrumen dari 45 item pertanyaan. Dari 45 item pertanyaan tersebut diperoleh 33 item yang dinyatakan valid dan reliabel sehingga dapat digunakan sebagai alat ukur yang baik dan 12 item dinyatakan tidak valid dan tidak reliabel.

Selanjutnya data penelitian minat membaca dari 33 item terhadap 37 siswa SMA Negeri 1 Koto XI Tarusan, dilihat dari perhitungan angket minat membacanya yang disebarkan kepada sampel penelitian dan mewakili seluruh siswa kelas X SMA Negeri 1 Koto XI Tarusan menunjukan bahwa pengaruh minat membaca terhadap hasil belajar sejarah berada pada tingkatan tinggi.

Seterusnya jika dari data hasil belajar siswa SMA Negeri 1 Koto XI Tarusan kelas X menunjukkan bahwa hasil belajar siswa yang dijadikan wakil sampel dari populasi dikategorikan nilai sejarahnya rendah. Kategori rendah tersebut didapat dari pengolahan data hasil belajar siswa kelas X SMA Negeri 1 Koto XI Tarusan.

Berdasarkan pengujian hipotesis, diketahui belajar siswa secara umum diperoleh harga r sebesar 0,901 > $r_{\text {tabel }}$ 0,325. Setelah dilakukan uji-t diketahui bahwa $t_{\text {hitung }} 19,2322>$ $t_{\text {tabel }} 2,042$, pada taraf signifikan 5\%. Hal ini menunjukkan bahwa hipotesis yang mengatakan terdapat pengaruh yang berarti antara minat membaca terhadap hasil belajar sejarah siswa SMA Negeri 1 Koto XI Tarusan diterima pada taraf signifikan 5\%. Minat membaca berpengaruh 
terhadap hasil belajar sejarah dan digolongkan pada kategori sangat kuat atau sangat tinggi terletak pada angka $0.80-1.000$, seperti tabel 4.3

Tabel 4.3

Tebel Menginterpretasikan Hasil Koefisien Korelasi

\begin{tabular}{|l|l|}
\hline Besarnya "r" Product Moment & \multicolumn{1}{|c|}{ Interpretasi } \\
\hline $\mathbf{0 . 0 0}-\mathbf{0 . 1 9 9}$ & $\begin{array}{l}\text { antara variabel X dan variabel Y terdapat } \\
\text { korelasi, tetapi sangat lemah atau sangat } \\
\text { rendah: sehingga korelasi diabaikan ( } \\
\text { dianggap tidak ada korelasi variable X } \\
\text { dan variabel Y }\end{array}$ \\
\hline $\mathbf{0 . 2 0}-\mathbf{0 . 3 9 9}$ & $\begin{array}{l}\text { Antara variabel X dan variabel Y } \\
\text { terdapat korelasi yang lemah atau rendah }\end{array}$ \\
\hline $\mathbf{0 . 4 0}-\mathbf{0 . 5 9 9}$ & $\begin{array}{l}\text { Antara variabel X dan variabel Y } \\
\text { terdapat korelasi yang sedang atau cukup }\end{array}$ \\
\hline $\mathbf{0 . 6 0}-\mathbf{0 . 7 9 9}$ & $\begin{array}{l}\text { Antara variabel X dan variabel Y } \\
\text { terdapat korelasi yang kuat atau tinggi }\end{array}$ \\
\hline $\mathbf{0 . 8 0}-\mathbf{1 . 0 0 0}$ & $\begin{array}{l}\text { Antara variabel X dan variabel Y } \\
\text { terdapat korelasi yang sangat kuat dan } \\
\text { sangat tinggi }\end{array}$ \\
\hline
\end{tabular}

Berdasarkan interpretasi dan analisa data di atas dapat disimpulkan bahwa hipotesa alternatif (Ha) diterima sedangkan hipotesa inisial (Hi) ditolak. Dengan demikian, terdapat pengaruh yang positif antara minat membaca terhadap hasil belajar siswa pada mata pelajaran sejarah kelas X SMA 1 Koto XI Tarusan. Namun, untuk kontribusi minat membaca dengan hasil belajar sejarah siswa terdapat $81 \%$ dan sisanya ditentukan oleh variabel lain.

\section{Simpulan}

Berdasarkan analisis data dan pembahasan yang telah dikemukakan pada bab terdahulu, maka dari hasil penelitian dapat dikemukakan kesimpulan dan saran-saran sebagai berikut:

1. Minat membaca terhadap pelajaran sejarah di SMA Negeri 1 Koto XI Tarusan berada pada kategori rendah, terlihat pada nilai pencapaian minat membaca siswa yang hanya berada pada tingkat $34 \%$. 
2. Hasil belajar siswa pada mata pelajaran sejarah di SMA Negeri 1 Koto XI Tarusan berada pada kategori rendah, terlihat pada rekapitulasi jawaban responden pada kategori tinggi hanya sebanyak 21 orang siswa.

3. Terdapat pengaruh yang positif dan signifikan antara minat membaca terhadap hasil belajar sejarah siswa pada mata pelajaran sejarah SMA Negeri 1 Koto XI Tarusan. Adanya pengaruh yang berarti tersebut ditunjukkan oleh koofisien korelasi $r$ hitung $(0,901)>r$ tabel $(0,325$ dan $\mathrm{t}$ hitung $(19,232)>\mathrm{t}$ tabel $(2,042)$. Ini berarti bahwa terdapat pengaruh yang positif dan signifikan antara minat membaca terhadap hasil belajar siswa pada mata pelajaran sejarah SMA Negeri 1 Koto XI Tarusan. Kontribusi pengaruh minat membaca terhadap hasil belajar sejarah siswa yaitu sebesar $81 \%$ dan $19 \%$ kontribusi lainnya.

Berdasarkan penelitian, pembahasan dan kesimpulan yang telah disampaikan di atas, maka ada beberapa saran yang ingin peneliti sampaikan.

1. Untuk menunjang peningkatan hasil belajar siswa ke arah yang lebih baik. Seorang guru harus memperhatikan faktor-faktor yang akan mempengaruhi hasil belajar siswa yaitu diantaranya Intelegensi, Perhatian, Minat, Bakat, Motivasi, Kematangan dan Kesiapan karena hal tersebut menjadi dasar seorang guru melihat keadaan hasil belajar siswanya dan menjadi patokan untuk meningkatkan hasil belajar siswa.

2. Kepala SMA Negeri 1 Koto XI Tarusan diharapkan untuk lebih meningkatkan kemampuannya atau kompetensi guru di dalam proses pembelajaran untuk meningkatkan minat membaca terhadap siswa pada setiap pertemuan karena dalam penelitian ini dibuktikan bahwa minat membaca juga memiliki pengaruh atau menentukan hasil belajar siswa.

3. Siswa hendaklah memiliki minat membaca yang lebih tinggi untuk memahami dan mencari mengenai informasi setiap pelajaran sehingga hal tersebut akan memiliki danpak terhadap hasil belajar siswa nantinya.

\section{DAFTAR PUSTAKA}

Agung, Leo. 2012. Sejarah Asia Timur I. Yogyakarta: Ombak.

Abdurrahman, Mulyono. 2003. Pendidikan Bagi Anak Berkesulitan Belajar. Jakarta: PT. Rineka Cipta. 2003

Arikunto, Suharsimi. 2008. Prosedur Penelitian Suatu Pendidikan Praktik. Jakarta: Rineka Cipta. 2008

540 | Seminar Nasional Sejarah ke 4 Jurusan Pendidikan Sejarah Universitas Negeri Padang 
Crow, D Lester. 1982. Educational Psychology, terj. Drs. Z. Kasijan. Surabaya: Bina Ilmu.

Dalman. 2013. Keterampilan Membaca. Jakarta: PT RajaGrafindo Persada.

Dalyono. 2005. Psikologi Pendidikan. Jakarta: Rineka Cipta.

Dalyono. 2012. Psikologi Pendidikan. Jakarta: Rineka Cipta.

Danim, Sudarwan. 2010. Profesi Kependidikan. Bandung: Alfabeta.

Daryanto. 2010. Belajar dan Mengajar. Bandung: Yrama Widya.

Djamarah, Syaiful Bahri. 2010. Guru dan Anak Didik dalam Interaksi Edukatif. Jakarta: PT Rineka Cipta.

Emzir. 2013. Metodologi Penelitian Pendidikan Kuantitatif \& Kualitatif. Jakarta: PT. Raja Grafindo Persada.

Hamalik Oemar. 2008. Proses Belajar Mengajar. Jakarta : PT Bumi Aksara.

Hamalik,Oemar. 2011. Kurikulum dan Pembelajaran. Jakarta: Bumi Aksara.

Hamka. 1998. Tafsir al-Azhar. Jakarta: PT. Bina Ilmu.

Hasbullah, Moeflih. Dedi Supriadi. 2012. Filsafat Sejarah. Bandung: Pustaka Setia.

Hurlock, Elizabeth. 1990. Psikologi Perkembangan. Jakarta: Erlangga.

Khodijah, Nyayu. 2014. Psikologi Pendidikan. Jakarta: PT. RajaGrafindo Persada.

Kuder, G. Frederic dan Blance D. Paulson. 1982. Pengembangan Bakat dan Minat. Yogyakarta: Pustaka Pelajar.

Marimba, D. Ahmad. 1980. Pengantar Filsafat Pendidikan Islam. Bandung: PT. Alma'arif.

Nasution, A.S. 1976. Bacaan dan Analisis Pendidikan. Jakarta: Gunung Agung.

Priyanto, Duwi. 2013. Mandiri Belajar Analisis data Dengan SPSS. Yogyakarta: Mediakom. Ramayulis. 2008. Ilmu Pendidikan Islam. Jakarta: Kalam Mulia.

Ridwan. 2009. Belajar Mudah Penelitian. Bandung : Alfabeta.

Riyanto, Yatim. 2009. Paradigma baru pembelajaran. Jakarta: Kencana Prenada Media Group.

Rochmat, Saefur. 2009. Ilmu Sejarah dalam Perspektif Ilmu Sosial. Yogyakarta: Graha Ilmu.

Saleh, Abdurahman. 1976. Didaktik Pendidikan Agama. Jakarta: Bulan Bintang.

Shahuddin, Mahfudh. 1990. Pengantar Psikologi Pendidikan. Surabaya: Bina Ilmu.

Shamad, A Irhash. 2003. Ilmu Sejarah, Perspektif Metodologis Dan Acuan Penelitian. Jakarta: Hayfa Press.

Slameto. 2003. Belajar dan Faktor-Faktor yang Mempengaruhinya. Jakarta: PT Rineka Cipta. Sudijono, Anas. 2009. Pengantar Evaluasi Pendidikan. Jakarta:PT RajaGrafindo Persada. 
Sudjana, Nana. 2009. Penilaian Hasil Proses Belajar Mengajar. Bandung: PT Remaja Rosdakarya.

Sugiyono. 2010. Metode Penelitian Kuantitatif Kualitatif Dan $R \& D$. Bandung: Alfabeta.

Sugiyono. 2013. Metode Penelitian Kombinasi. Bandung: Alfabeta.

Sujarweni, Wiratna. 2014. Metodologi Penelitian lengkap, Praktis, dan Mudah Dipahami. Yogyakarta: Pustaka Baru Press.

Sukardi. 2003. Metodologi Penelitian Pendidikan, Kompetensi dan Prakteknya. Jakarta: Bumi Aksara.

Suparno, Paul. 1997. Filsafat Konstruksivisme dalam Pendidikan. Yogyakarta: Kanisius.

Suyanto, Agus. 2005. Psikologi Perkembangan. Jakarta: Aksara Baru.

Syah, Muhibbin. 2007. Psikologi Pendidikan Dengan Pendekatan Baru. Bandung: PT. Remaja Rosdakarya.

Trianto. 2014. Model Pembelajaran Terpadu. Jakarta: Bumi Aksara.

Wahadaniah, Herman. 1997. Perpustakaan Sekolah sebagai Sarana Pengembangan Minat dan Kegemaran Membaca. Jakarta: Departemen Pendidikan dan Kebudayaan.

Winarno, Surachman. 1998. Psikologi Pemuda. Bandung: Jemmar. 